\title{
Changes in blood concentrations of trace metals in cancer patients receiving cisplatin-based chemotherapy
}

\author{
TSUTOMU NAKAMURA ${ }^{1,2}$, MINORU TAKAHASHI ${ }^{2}$, RIHO NIIGATA $^{3}$, \\ KAZUHIKO YAMASHITA ${ }^{4}$, MANABU KUME ${ }^{4}$, MIDORI HIRAI $^{4}$ and HIROYUKI YASUI ${ }^{3}$ \\ ${ }^{1}$ Education and Research Center for Clinical Pharmacy, Osaka University of Pharmaceutical Sciences, Takatsuki, \\ Osaka 569-1094; ${ }^{2}$ Department of Pharmaceutical Health Care, Faculty of Pharmaceutical Sciences, Himeji Dokkyo \\ University, Himeji, Hyogo 670-8524; ${ }^{3}$ Department of Analytical and Bioinorganic Chemistry, Kyoto Pharmaceutical \\ University, Kyoto 607-8414; ${ }^{4}$ Department of Pharmacy, Kobe University Hospital, Kobe, Hyogo 650-0017, Japan
}

Received September 7, 2016; Accepted October 19, 2016

DOI: $10.3892 /$ br.2016.789

\begin{abstract}
The administration of cisplatin (CDDP) may influence trace metal concentrations in body fluids. In order to test this hypothesis, the blood concentrations of trace metals were determined during the present study in eight Japanese esophageal and lung cancer patients receiving CDDP-based chemotherapy. The levels of manganese, iron (Fe), cobalt, copper, zinc $(\mathrm{Zn})$, platinum and lead in the plasma were determined by inductively coupled plasma-mass spectrometry. In addition, the serum levels of Fe, transferrin and ferritin were evaluated. The baseline plasma concentration of $\mathrm{Fe}$ in patients with esophageal cancer was significantly lower than that in lung cancer patients $(\mathrm{P}=0.011)$, although there were no significant differences identified with respect to the plasma levels of other trace metals. The data obtained from six fasting patients without blood transfusion demonstrated that plasma concentrations of Fe increased 3.5-fold soon after CDDP treatment and returned to baseline levels $\sim 10$ days after therapy. The excessive Fe levels in the bloodstream induced changes in serum ferritin and transferrin levels. Furthermore, serum $\mathrm{Zn}$ levels increased 1.8-fold in the 1-3 days following CDDP treatment, and serum cystatin $\mathrm{C}$ levels transiently increased. These findings indicate that serum $\mathrm{Fe}$ and $\mathrm{Zn}$ levels may be useful to understanding the physiological responses in the early stages of CDDP-based chemotherapy, which may be associated with systemic inflammation and/or tissue distribution of CDDP.
\end{abstract}

Correspondence to: Professor Tsutomu Nakamura, Education and Research Center for Clinical Pharmacy, Osaka University of Pharmaceutical Sciences, 4-20-1 Nasahara, Takatsuki, Osaka 569-1094, Japan

E-mail: tsutomun@gly.oups.ac.jp

Key words: trace metal, cisplatin, iron, esophageal cancer, lung cancer

\section{Introduction}

Cisplatin (CDDP) is one of the most potent anticancer therapeutic agents in clinical use. It is applied in the treatment of various common types of solid tumor found in tissues, such as the esophagus and the lungs. However, CDDP is frequently associated with renal tubular dysfunction and cumulative impairment in renal function is a dose-limiting factor in the administration of this anticancer agent $(1,2)$. The mechanism of CDDP-induced nephrotoxicity is not completely understood. However, the primary cause of dysfunction is considered to be the high concentration of CDDP uptake into renal cells, particularly renal proximal tubular cells, relative to other tissues $(3,4)$. Moreno-Gordaliza et al (5) performed fertility laser ablation inductively coupled plasma mass spectrometry bioimaging analysis, which demonstrated that platinum $(\mathrm{Pt})$ displaced zinc $(\mathrm{Zn})$ and copper $(\mathrm{Cu})$ within renal cells of CDDP-treated rats. This result indicates the possibility of limited tissue distribution of these types of metal and consequent changes in their blood levels in the early phase of CDDP-based chemotherapy. Additionally, there is the possibility that CDDP administration influences the concentrations of other metals in body fluids. However, there is little information regarding time-concentration profiles of trace metals during CDDP-based chemotherapy.

The aim of the present study was to determined the plasma levels of trace metals, including manganese $(\mathrm{Mn})$, iron (Fe), cobalt $(\mathrm{Co}), \mathrm{Cu}, \mathrm{Zn}$, and lead $(\mathrm{Pb})$ in Japanese esophageal and lung cancer patients receiving CDDP-based chemotherapy.

\section{Materials and methods}

Patients and blood samples. The protocol for the current study was approved by Ethics Committee of Kobe University Hospital (Kobe, Japan). Written informed consent was obtained from all patients before the start of the study. Eight patients received neoadjuvant or adjuvant CDDP-based chemotherapy for esophageal squamous cell carcinoma and lung adenocarcinoma at Kobe University Hospital (February 2011 to July 2011). The clinical characteristics of the patients in the current study are presented in Table I. The study protocols of CDDP-based 
Table I. Patient characteristics and baseline values of laboratory tests and plasma trace metals in patients with esophageal and lung cancer.

\begin{tabular}{|c|c|c|c|}
\hline Primary site of disease (histology) & Esophagus (squamous cell carcinoma) ${ }^{\mathrm{a}}$ & Lung (adenocarcinoma) & P-value \\
\hline Age, years & $\begin{array}{l}64.6 \pm 11.4 \\
70(55-72)\end{array}$ & $\begin{array}{l}66.0 \pm 7.0 \\
66(59-73)\end{array}$ & 0.837 \\
\hline Gender, m/f & $4 / 1$ & $1 / 2$ & 0.464 \\
\hline Surgical history, yes/no & $0 / 5$ & $2 / 1$ & 0.107 \\
\hline Serum creatinine, $\mathrm{mg} / 100 \mathrm{ml}$ & $\begin{array}{c}0.86 \pm 0.21 \\
0.95(0.86-0.99)\end{array}$ & $\begin{array}{c}0.66 \pm 0.05 \\
0.65(0.64-0.68)\end{array}$ & 0.094 \\
\hline Plasma cystatin $\mathrm{C}, \mathrm{mg} / 100 \mathrm{ml}$ & $\begin{array}{c}0.76 \pm 0.14 \\
0.79(0.64-0.80)\end{array}$ & $\begin{array}{c}0.68 \pm 0.16 \\
0.59(0.59-0.72)\end{array}$ & 0.517 \\
\hline eGFR, $\mathrm{ml} \mathrm{min} \min ^{-1} 1.73 \mathrm{~m}^{-2}$ & $\begin{array}{c}68.6 \pm 16.6 \\
65.0(57.5-66.0)\end{array}$ & $\begin{array}{c}75.6 \pm 8.0 \\
71.3(71.0-78.1)\end{array}$ & 0.456 \\
\hline Serum aspartate transaminase, IU/ml & $\begin{array}{c}20 \pm 6 \\
18(16-19)\end{array}$ & $\begin{array}{r}17 \pm 3 \\
18(16-19)\end{array}$ & 0.385 \\
\hline Serum alanine aminotransferase, IU/ml & $\begin{array}{r}20 \pm 12 \\
15(12-21)\end{array}$ & $\begin{array}{r}14 \pm 2 \\
15(14-16)\end{array}$ & 0.397 \\
\hline Total bilirubin, $\mathrm{mg} / 100 \mathrm{ml}$ & $\begin{array}{c}0.5 \pm 0.2 \\
0.5(0.4-0.7)\end{array}$ & $\begin{array}{r}0.5 \pm 0.2 \\
0.5(0.4-0.6)\end{array}$ & 0.713 \\
\hline Serum albumin, $\mathrm{g} / 100 \mathrm{ml}$ & $\begin{array}{c}3.5 \pm 0.4 \\
3.7(3.2-3.7)\end{array}$ & $\begin{array}{r}4.0 \pm 0.2 \\
4.0(3.9-4.1)\end{array}$ & $0.042^{\mathrm{b}}$ \\
\hline Red blood cells, $\times 10^{4}$ cells $/ \mu 1$ & $\begin{array}{c}410 \pm 32 \\
394(394-434)\end{array}$ & $\begin{array}{c}422 \pm 29 \\
415(406-434)\end{array}$ & 0.629 \\
\hline Hemoglobin, $\mathrm{g} / 100 \mathrm{ml}$ & $\begin{array}{c}12.0 \pm 2.8 \\
13.0(11.7-13.6)\end{array}$ & $\begin{array}{c}11.8 \pm 1.2 \\
11.5(11.2-12.4)\end{array}$ & 0.902 \\
\hline White blood cells, $\mathrm{x} 10^{2}$ cells $/ \mu 1$ & $\begin{array}{c}84 \pm 34 \\
84(51-118)\end{array}$ & $\begin{array}{r}97 \pm 96 \\
47(42-128)\end{array}$ & 0.843 \\
\hline Platelet, $\times 10^{4}$ cells $/ \mu 1$ & $\begin{array}{c}20.4 \pm 9.5 \\
21.4(19.5-22.9)\end{array}$ & $\begin{array}{r}32.4 \pm 23.9 \\
19.3(18.7-39.7)\end{array}$ & 0.493 \\
\hline C-reactive protein, $>1.0 \mathrm{mg} / 100 \mathrm{ml}$ & $2(40 \%)$ & $1(33 \%)$ & 1.000 \\
\hline${ }^{55} \mathrm{Mn}, \mathrm{ng} / \mathrm{ml}$ & $\begin{array}{r}7.3 \pm 3.2 \\
6.4(4.8-8.1)\end{array}$ & $\begin{array}{c}16.3 \pm 5.1 \\
17.0(13.9-19.0)\end{array}$ & 0.072 \\
\hline${ }^{56} \mathrm{Fe}, \mathrm{ng} / \mathrm{ml}$ & $\begin{array}{c}1,719 \pm 369 \\
1,671(1,454-1,822)\end{array}$ & $\begin{array}{c}2,419 \pm 118 \\
2,360(2,351-2,458)\end{array}$ & $0.011^{\mathrm{b}}$ \\
\hline${ }^{63} \mathrm{Cu}, \mathrm{ng} / \mathrm{ml}$ & $\begin{array}{c}746 \pm 321 \\
667(636-851)\end{array}$ & $\begin{array}{c}824 \pm 36 \\
845(814-845)\end{array}$ & 0.617 \\
\hline${ }^{66} \mathrm{Zn}, \mathrm{ng} / \mathrm{ml}$ & $\begin{array}{c}1,928 \pm 584 \\
1,873(1,677-2,090)\end{array}$ & $\begin{array}{c}8,581 \pm 4,866 \\
8,212(6,061-10,917)\end{array}$ & 0.142 \\
\hline${ }^{208} \mathrm{~Pb}, \mathrm{ng} / \mathrm{ml}$ & $\begin{array}{c}54.6 \pm 7.7 \\
54.7(49.2-55.9)\end{array}$ & $\begin{array}{c}88.7 \pm 35.6 \\
89.4(71.1-106.7)\end{array}$ & 0.243 \\
\hline
\end{tabular}

Data are presented as means \pm standard deviation and median (interquartile range) or $\mathrm{n}(\%)$. ${ }^{\mathrm{a}}$ The plasma samples from our previous study (6) were reanalyzed for the trace metal analysis in the present study. ${ }^{b}$ Statistically significant difference between the two groups. $\mathrm{m}$, male; f, female; Mn, manganese; Fe, iron; $\mathrm{Cu}$, copper; $\mathrm{Zn}$, zinc; Pb, lead.

chemotherapy and blood sampling for esophageal cancer patients (patients 1-5) and lung cancer patients (patients 6-8) are presented in Fig. 1. The CDDP-based chemotherapy for esophageal squamous cell carcinoma consisted of a 2-h drip infusion of $80 \mathrm{mg} / \mathrm{m}^{2} \mathrm{CDDP}$ (Maruko cisplatin for i.v. infusion; Yakult, Tokyo, Japan) on day 1 and a 5-day protracted venous infusion of $800 \mathrm{mg} / \mathrm{m}^{2}$ per day fluorouracil on days $1-5$. For lung adenocarcinoma, treatment consisted of a 2-h drip infusion of $75 \mathrm{mg} / \mathrm{m}^{2} \mathrm{CDDP}$ and $500 \mathrm{mg} / \mathrm{m}^{2}$ pemetrexed (Alimta ${ }^{\circledR}$ Injection; Eli Lilly and Co., Indianapolis, IN, USA) on day 1.
The patients received appropriate hydration and antiemetic premedication consisting of $1 \mathrm{mg}$ granisetron (Granisetron intravenous solution; Meiji Seika Pharma Co., Tokyo, Japan) on day 1, $6.6 \mathrm{mg}$ dexamethasone (DEXART ${ }^{\circledR}$ injection; Fuji Pharma Co., Toyama, Japan) on day 1 and $3.3 \mathrm{mg}$ dexamethasone on days 2 and 3), and $125 \mathrm{mg}$ aprepitant (EMEND ${ }^{\circledR}$ Capsule; Ono Pharmaceutical Co., Osaka, Japan) on day 1 and $80 \mathrm{mg}$ aprepitant on days 2 and 3. One esophageal cancer patient (patient 1 ) received $0.75 \mathrm{mg}$ palonosetron (Aloxi ${ }^{\circledR}$ i.v. injection; Taiho Pharmaceutical Co., Tokyo, Japan) on day 1 


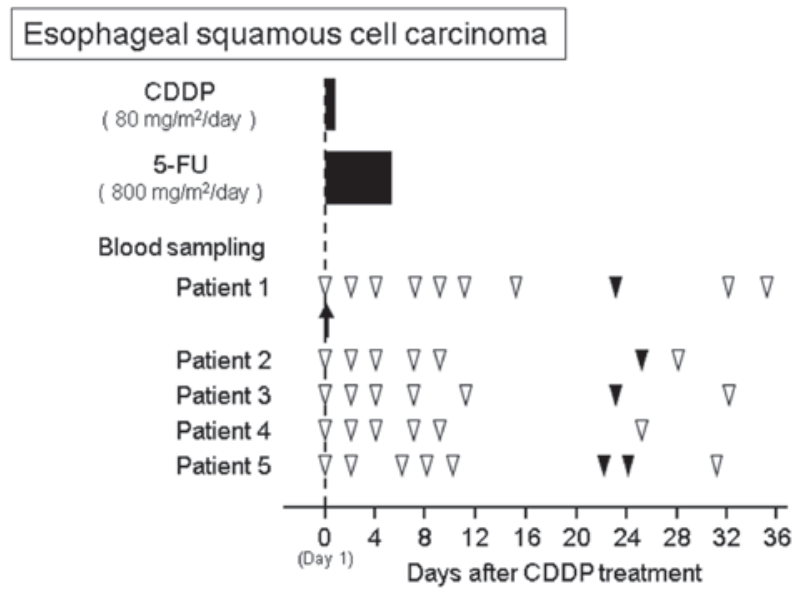

Lung adenocarcinoma

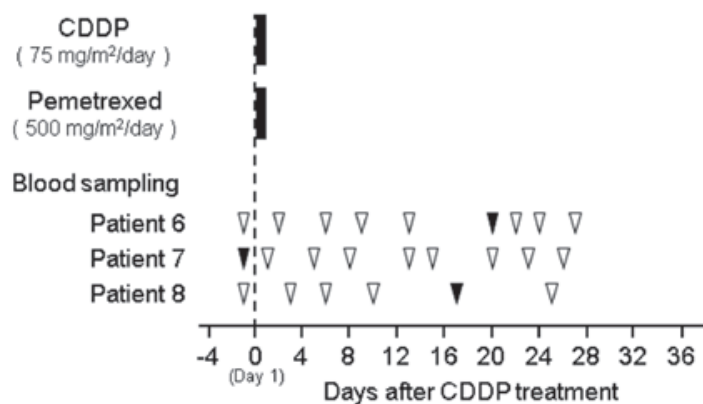

Figure 1. Study protocols of CDDP-based chemotherapy and blood sampling for esophageal (patients 1-5) and lung (patients 6-8) cancers. Patient 1 was anemic and required a single red blood cell transfusion on day 1 (indicated by the arrow). Blood samples were collected in fasting (open triangle) and non-fasting (closed triangle) states. CDDP, cisplatin; 5-FU, 5-fluorouracil.

rather than granisetron. This patient had anemia and required a single red blood cell transfusion on day 1 . Subsequently, the patient took oral iron pills every day during the observation period.

Peripheral venous blood $(5 \mathrm{ml})$ was drawn at 6-10 time-points from each patient into duplicate tubes, either containing or not containing ethylenediaminetetraacetic acid (EDTA). The first blood sample was taken 1-3 days after the start of the CDDP infusion, and samples were taken at 2- to 16-day intervals thereafter. Baseline measurements were taken one day before or at the start of CDDP administration. Blood samples containing EDTA were immediately centrifuged at room temperature $\left(18-25^{\circ} \mathrm{C}\right)$ for $10 \mathrm{~min}$ at $1,900 \mathrm{x} \mathrm{g}$ to provide a plasma sample for the determination of plasma concentrations of trace metals, and samples without EDTA were used for routine and additional laboratory tests. The time-blood concentration profiles of Pt in the five patients with esophageal cancer were assessed during chemotherapy in our previous study (6), and the plasma samples of the study were reanalyzed during the present study for trace metal analysis. The variability in plasma concentrations of trace metals during the observation period were assessed as fold-increases relative to the baseline level. To minimize confounding influences from circadian variations in trace metal concentrations and clinical laboratory tests, the serum sampling was performed in the fasted state, and always at 5:30 a.m., to obtain samples for the additional clinical laboratory tests. Serum Fe, magnesium, ferritin, and transferrin were analyzed in accordance with standard biochemical methods at LSI Medience Corp. (Tokyo, Japan). The plasma and serum samples were stored at $-40^{\circ} \mathrm{C}$ prior to testing.

Determination of plasma concentrations of trace metals. The concentrations of trace metals in plasma were determined as described previously (6). Briefly, each sample $(50 \mu \mathrm{l})$ was reduced to ash by repeated treatment with nitric acid [for poisonous metal determination; Wako Pure Chemical Industries (Osaka, Japan)], hydrogen peroxide (for atomic absorption spectrochemical analysis; Wako) and perchloric acid (for poisonous metal determination; Wako) at $200^{\circ} \mathrm{C}$. Sample ash was dissolved in $5 \mathrm{ml}$ of $5 \%$ nitric acid and analyzed by inductively coupled plasma mass spectrometry (ICP-MS) using Agilent 7700x ICP-MS (Agilent Technologies, Inc., Santa Clara, CA, USA). The levels of $\mathrm{Mn}, \mathrm{Fe}, \mathrm{Co}, \mathrm{Cu}$, $\mathrm{Zn}, \mathrm{Pt}$ and $\mathrm{Pb}(\mathrm{m} / \mathrm{z}=55,56,59,63,66,195$ and 208, respectively) were determined in two or three replicates per sample. Contamination from tubes and other sources was avoided. The trace metal concentrations in each sample were calculated using linear regression of the standard curves prepared using standard solutions of the respective trace metals. The standard curves exhibited linear regression in the range of 1-500 ng/ml $(\mathrm{r}=0.999)$ and the limit of quantification was $0.1 \mathrm{ng} / \mathrm{ml}$.

Measurement of serum levels of Fe, magnesium, ferritin and transferrin. Serum levels of $\mathrm{Fe}$, magnesium and transferrin were measured using a colorimetric assay (Quick Auto Neo Fe; Shino-Test Corp., Tokyo, Japan) according to the manufacturers' instructions, an emzymatic assay (IATRO LQ Mg rate II; LSI Medience Corp.) and a turbidimetric immunoassay (N-Assay TIA Tf-H Nittobo; Nitto Boseki Co., Ltd., Tokyo, Japan), respectively, with an automated clinical chemistry analyzer (System H7700; Hitachi High-Tequnologies Corp., Tokyo, Japan). The serum ferritin level was measured using a chemiluminiscent immunoassay (Chemilumi ACS-Ferritin II; Siemens Healthcare Diagnostics, Tokyo, Japan) with a Chemilumi ADVIA Centaur (Siemens Healthcare diagnostics). The results were routinely validated to confirm acceptable precision and accuracy.

Statistical analysis. The pharmacokinetic parameters were calculated from the individual plasma Pt concentration-time curve as described previously (6). Data are expressed as the mean \pm standard deviation (SD) or median and quartile range. Fisher's exact test and Welch's test were used for statistical analysis of the two groups. The differences in rates of change, for raw or mean values from individual laboratory tests, between baseline and treatment days after initiation of chemotherapy were evaluated using Steel-Dwass multiple comparison test. Two-tailed $\mathrm{P}<0.05$ was considered to indicate a statistically significant difference.

\section{Results}

Patient characteristics and baseline values of the laboratory tests and plasma trace metals. Serum albumin levels in patients with esophageal cancer were identified to be significantly lower than those of the lung cancer patients $(\mathrm{P}=0.042)$, 
whereas no significant difference in renal and hepatic function indices were identified between the two groups (Table I). In addition, no significant difference was identified between the groups in red and white blood cell counts, platelet counts or in the hemoglobin and C-reactive protein levels in the blood. The mean \pm SD baseline plasma concentration of ${ }^{56} \mathrm{Fe}$ in patients with esophageal cancer was $1,719 \pm 369 \mathrm{ng} / \mathrm{ml}$, and the value was significantly lower than that in lung cancer patients $(2,419 \pm 118 \mathrm{ng} / \mathrm{ml} ; \mathrm{P}=0.011)$. No significant differences in the mean values of other trace metals were identified between the esophageal and lung cancer patients. The baseline plasma concentrations of ${ }^{195} \mathrm{Pt}$ and those of ${ }^{59} \mathrm{Co}$ at almost all sampling points were below the limit of quantification.

Time-plasma concentrations of trace metals. Fig. 2 demonstrated the time-plasma concentrations of trace metals in eight patients receiving CDDP-based chemotherapy. The fold-change values of the plasma concentrations from baseline were in the range 0.1-5.5 for ${ }^{55} \mathrm{Mn}, 0.6-1.9$ for ${ }^{56} \mathrm{Fe}$, 0.7-2.3 for ${ }^{63} \mathrm{Cu}, 0.3-3.9$ for ${ }^{66} \mathrm{Zn}$, and $0.4-10.0$ for ${ }^{208} \mathrm{~Pb}$ during the observation period. When the plasma Pt concentrations were calculated by adjusting for the CDDP dose at the start of the treatment in patients with esophageal and lung cancer (6) there was a statistically significant difference between their mean $\pm \mathrm{SD}$ values $\left[6.8 \pm 0.8\right.$ and $8.7 \pm 0.9 \mathrm{ng} \mathrm{ml}^{-1}(\mathrm{mg} \mathrm{CDDP})^{-1}$, respectively; $\mathrm{P}=0.044]$. No significant difference in the elimination rate constant and half-life was identified between the esophageal and lung cancer patients.

Variability of plasma trace metal concentrations. Fig. 3 shows the variability of plasma trace metal concentrations during the observation period. To minimize confounding influences of circadian variation and supplemental treatment on trace metal levels, two patients were excluded from the analysis: One lung cancer patient had consumed food prior to baseline blood sampling, and another patient with esophageal cancer required a single red blood cell transfusion and had taken oral iron pills. For the six patients included, the variability of plasma concentrations of trace metals during the observation period was assessed (Fig. 3). In these patients, the plasma concentrations of ${ }^{56} \mathrm{Fe}$ and ${ }^{66} \mathrm{Zn}$ increased during the 1-3 days following the start of CDDP treatment. Subsequently, the plasma concentrations of ${ }^{56} \mathrm{Fe}$ declined to baseline levels by around the tenth day for all patients, whereas ${ }^{66} \mathrm{Zn}$ plasma concentrations changed gradually during the observation period. Plasma concentrations of other trace metals $\left({ }^{55} \mathrm{Mn},{ }^{63} \mathrm{Cu}\right.$ and $\left.{ }^{208} \mathrm{~Pb}\right)$ did not exhibit any characteristic changes.

Variability of laboratory test values. In the six patients, the median (interquartile range) baseline serum levels of Fe, magnesium, ferritin and transferrin were $67.0(61.0-93.3) \mu \mathrm{g} / 100 \mathrm{ml}$, $2.4(2.3-2.5) \mathrm{mg} / 100 \mathrm{ml}, 104.9(73.8-151.5) \mathrm{ng} / \mathrm{ml}$, and 208.0 (191.0-237.8) mg/100 ml, respectively. When serum Fe levels were determined by the colorimetric method, its transient elevation, similar to that of ${ }^{56} \mathrm{Fe}$ determined by the ICP-MS method, was observed more clearly (Fig. 4A). Serum magnesium levels were also determined enzymatically and had a tendency to decrease during the observation period, although this was not statistically significant (Fig. 4B). The serum levels of ferritin significantly increased on days 1-3
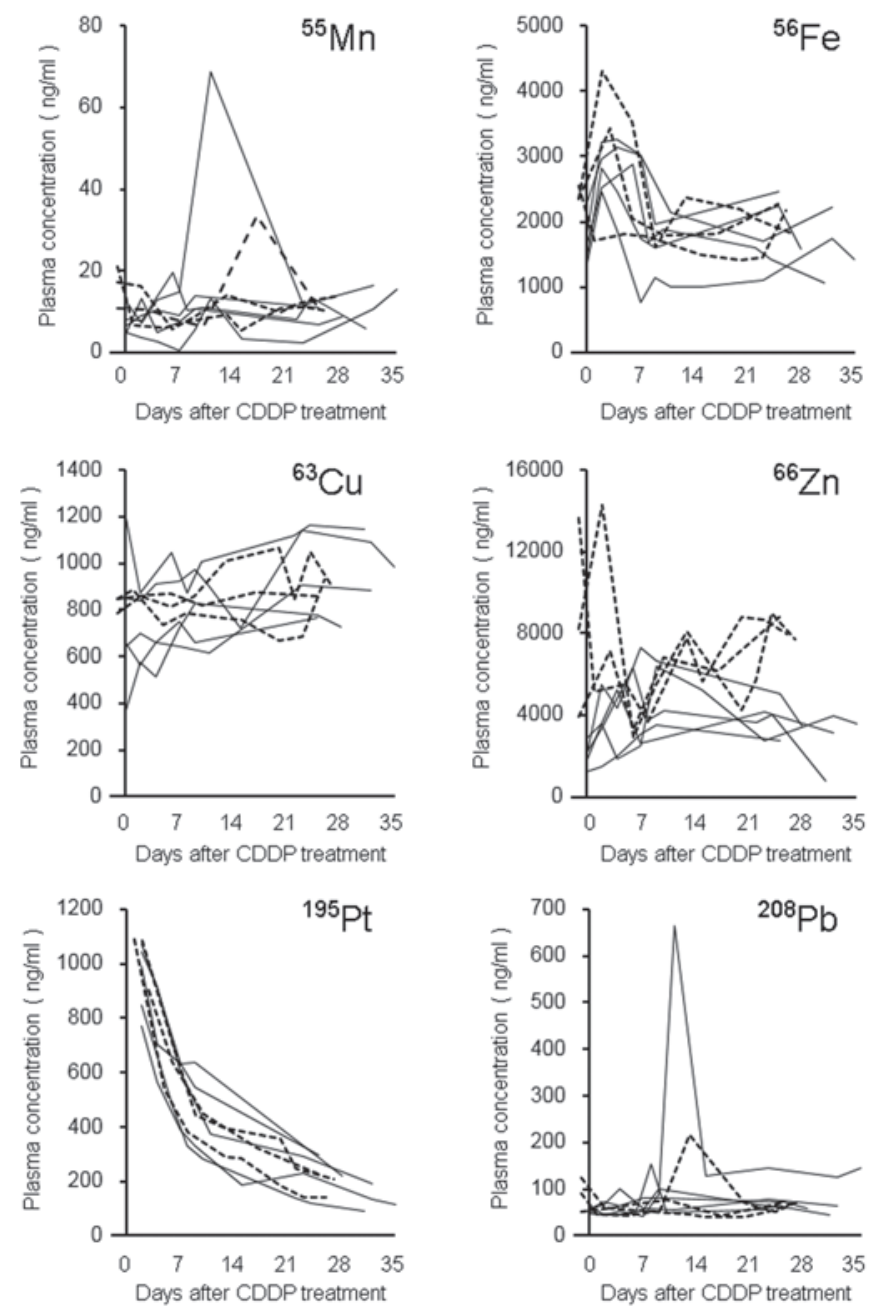

Figure 2. Time-concentration profiles of trace metals in plasma following CDDP treatment in eight patients with esophageal (solid line; $n=5$ ) and lung (dotted line; $n=3$ ) cancer. The baseline data was obtained one day before or on the day of the CDDP treatment. CDDP, cisplatin; Mn, manganese; Fe, iron; $\mathrm{Cu}$, copper; $\mathrm{Zn}$, zinc; $\mathrm{Pt}$, platinum; $\mathrm{Pb}$, lead.

$(\mathrm{P}=0.018)$, and this increase was sustained until at least 10 days after CDDP treatment (Fig. 4C). Serum transferrin levels tended to be below the baseline levels at days 1-11 and on days 1-3 exhibited a significant difference (Fig. 4D; $\mathrm{P}=0.018$ ). The median (interquartile range) baseline values of red blood cells and hemoglobin were 406 (395-429) x $10^{4}$ cells $/ \mu 1$ and 13.1 (12.0-13.5) g/100 ml, respectively. These values showed a similar pattern of change during the observation period, exhibiting a marginal decrease on days 1-3 and a significant decrease approximately one month after CDDP treatment (Fig. 4E and F; $\mathrm{P}<0.05$ ).

Time-concentration profiles of plasma cystatin $C$ and serum creatinine levels. In our previous study, the transient elevation of the plasma concentration of cystatin $\mathrm{C}$ following CDDP treatment was observed in patients with esophageal cancer (6). In the present study, the plasma concentration profiles were evaluated in three patients with lung cancer in addition to patients with esophageal cancer (Fig. 5). Two lung cancer patients exhibited 1.29- and 1.39-fold increases in plasma 

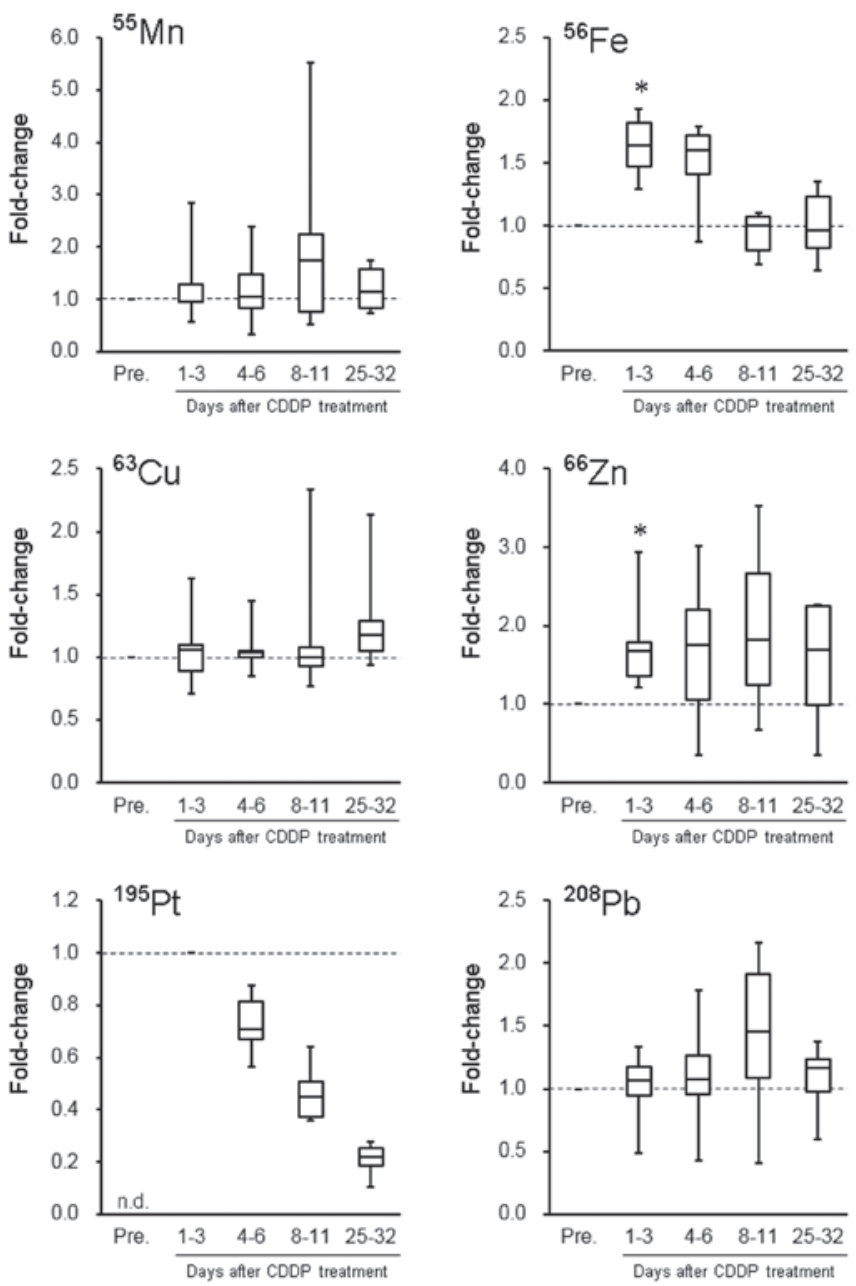

Figure 3. Variability in plasma concentrations of trace metals following CDDP treatment in six patients with esophageal $(n=4)$ and lung $(n=2)$ cancer. The data were processed individually for each patient as fold-change vs. baseline levels for ${ }^{55} \mathrm{Mn},{ }^{56} \mathrm{Fe},{ }^{63} \mathrm{Cu},{ }^{66} \mathrm{Zn}$ and ${ }^{208} \mathrm{~Pb}$, or as fold-change vs. data from 1-3 days following treatment for ${ }^{195} \mathrm{Pt}$ levels. The baseline data (Pre.) was obtained one day before or on the day of the CDDP treatment. The data for the patients who received a blood transfusion or had blood drawn while in non-fasting state were excluded from the analysis. ${ }^{~} \mathrm{P}<0.05$ vs. baseline. n.d., not detectable; CDDP, cisplatin; $\mathrm{Mn}$, manganese; $\mathrm{Fe}$, iron; $\mathrm{Cu}$, copper; $\mathrm{Zn}$, zinc; $\mathrm{Pb}$, lead; Pt, platinum.

cystatin C levels on days 1-3, compared with their baseline levels, and these levels subsequently returned to baseline within approximately one week. The other patient also demonstrated a similar tendency, exhibiting a 1.3-fold increase in plasma cystatin C levels after CDDP treatment $(0.66$ and $0.87 \mathrm{mg} / \mathrm{l}$ on days 1 and 5, respectively), although in this patient, baseline blood sampling was performed in the non-fasted state and, therefore, the level was $0.86 \mathrm{mg} / \mathrm{l}$. The change rates of serum creatinine levels in two patients were between 0.86 and 1.06 during the present observation period, based on their baseline levels, whereas the value in the other patient increased gradually by $\sim 1.3$.

\section{Discussion}

Trace metals including $\mathrm{Fe}, \mathrm{Zn}$, and $\mathrm{Cu}$ exist widely in the body and are important in the maintenance of physiological homeostasis. Fe is required for adequate erythropoietic
$\mathbf{A}$

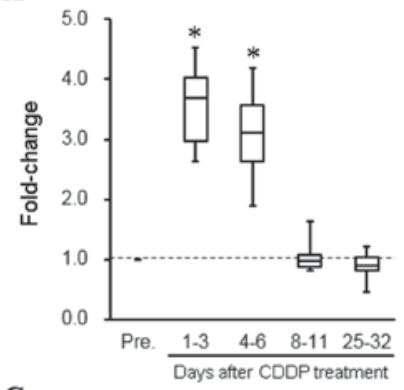

C

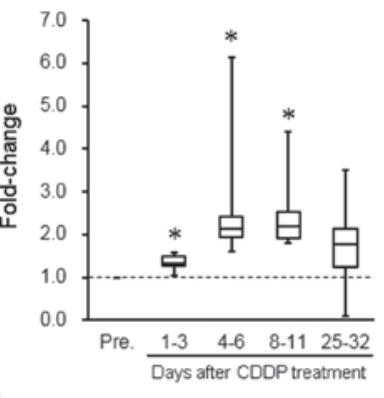

$\mathbf{E}$

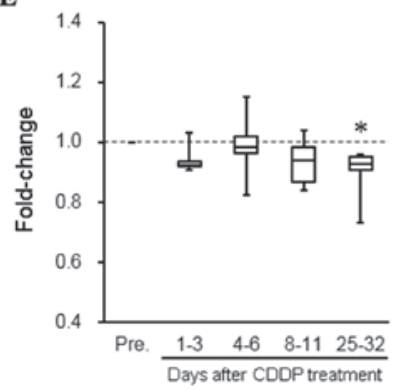

B
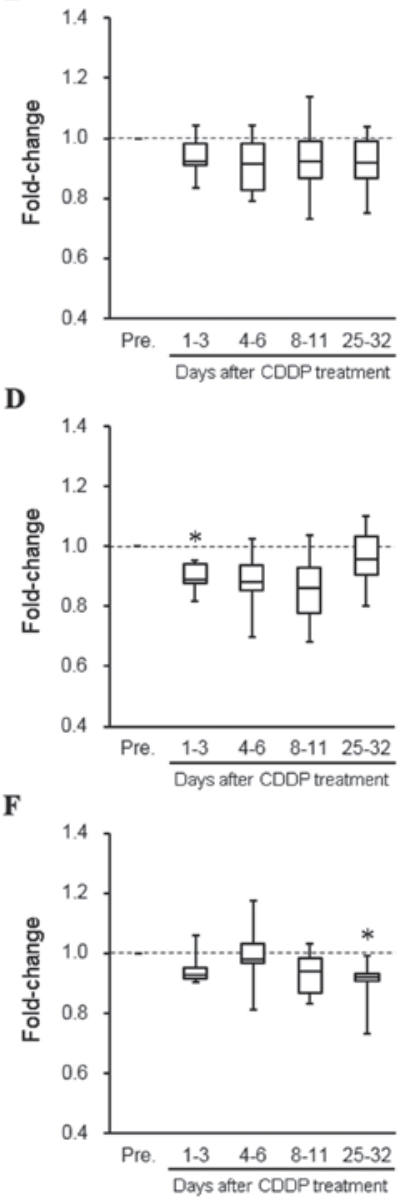

Figure 4. Variability of laboratory test values following CDDP treatment in six patients with esophageal $(n=4)$ and lung $(n=2)$ cancer. The laboratory tests include serum levels of (A) iron, (B) magnesium, (C) ferritin and (D) transferrin, (E) red blood cell counts, and (F) hemoglobin levels. The data were processed individually for each patient as a fold-increase vs. baseline (Pre.) levels. The baseline data was obtained one day before or on the day of the CDDP treatment. The data for the patients who received a blood transfusion or had blood drawn while in a non-fasting state were excluded from the analysis. ${ }^{*} \mathrm{P}<0.05$ vs. baseline. CDDP, cisplatin.

function (oxygen transport and storage), oxidative metabolism, and cellular immune response (7). $\mathrm{Zn}$ is required for general metabolism, and catalytic, structural and regulatory functions (8), and $\mathrm{Cu}$ is required for $\mathrm{Fe}$ metabolism, antioxidant defense, neuropeptide synthesis, and immune function (9). In the present study, serum concentrations of ${ }^{55} \mathrm{Mn},{ }^{56} \mathrm{Fe}$, ${ }^{63} \mathrm{Cu},{ }^{66} \mathrm{Zn},{ }^{59} \mathrm{Co}$ and ${ }^{208} \mathrm{~Pb}$ were determined in esophageal and lung cancer patients (Table I). In lung cancer patients who had not undergone cancer chemotherapy, the results demonstrated that serum levels of ${ }^{55} \mathrm{Mn},{ }^{56} \mathrm{Fe},{ }^{63} \mathrm{Cu}$ and ${ }^{208} \mathrm{~Pb}$ were in approximately the same range, whereas ${ }^{66} \mathrm{Zn}$ levels were beyond the range of values reported previously (10-14). The differences in trace metal concentrations may be partly explained by the different measurement methods that were used; atomic absorption spectrophotometry and ICP-MS. In the esophageal cancer patients of the present study, the baseline serum levels of ${ }^{56} \mathrm{Fe}$ and ${ }^{66} \mathrm{Zn}$ were apparently in the same range as that which was reported in a previous study on preoperative esophageal cancer patients (15). The levels of ${ }^{55} \mathrm{Mn},{ }^{59} \mathrm{Co},{ }^{63} \mathrm{Cu}$, ${ }^{66} \mathrm{Zn}$ and ${ }^{208} \mathrm{~Pb}$ were comparable with values in the lung cancer 

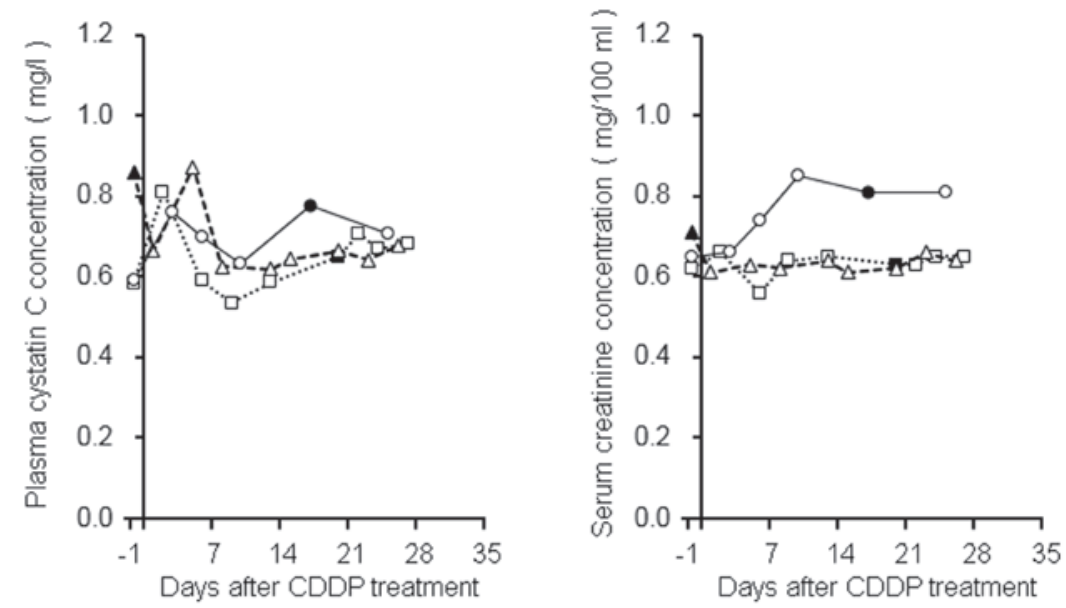

Figure 5. Time-concentration profiles of plasma cystatin $\mathrm{C}$ and serum creatinine levels following the CDDP treatment in three patients with lung cancer. Each line represents an individual time-concentration profile. Closed symbols represent the data for blood samples taken in a non-fasted state. CDDP, cisplatin.

patients while the ${ }^{56} \mathrm{Fe}$ levels were significantly lower. This may have been due to the anemia-associated lowering of values of serum ferritin and hemoglobin, as well as of serum Fe levels in one esophageal cancer patient, although it was unclear whether the other patients exhibited gastrointestinal tract bleeding.

$\mathrm{Pt}$ is a heavy metal and a constituent atom of CDDP, and there is a possibility that the administration of CDDP influences the trace metal concentrations in body fluids. Among the metals evaluated in the present study, the time-concentration profile of ${ }^{56} \mathrm{Fe}$ indicated that its plasma concentration was increased subsequent to CDDP treatment and returned to the baseline level within $\sim 10$ days. The current study, however, included two patients who had anemia or were in a non-fasted condition and, therefore, the blood transfusion, and consumption of iron tablets and a meal were considered as confounding factors. In order to eliminate these, the plasma levels of ${ }^{56} \mathrm{Fe}$ and other metals from data of all but these two patients were evaluated. The analysis yielded results that indicated a significant increase in plasma ${ }^{56} \mathrm{Fe}$ and ${ }^{66} \mathrm{Zn}$ levels in the $1-3$ days following CDDP treatment (Fig. 3). In addition, the serum Fe levels were evaluated using a colorimetric method, which more clearly confirmed the same tendency (Fig. 4A). This may be due to the difference in ability to remove the $\mathrm{Fe}$ from the serum proteins between chelating and ashing. Fe in the body is largely stored in erythrocyte hemoglobin, and the liver and spleen are also Fe-rich tissues (16). As shown in Fig. 4E and F, red blood cell counts and hemoglobin levels have a tendency to decrease, which may contribute to the elevation of serum $\mathrm{Fe}$ levels, although the difference was not statistically significant. Ferritin is one of the proteins that stores $\mathrm{Fe}$ in the tissues. In the current study, its serum level increases gradually after CDDP treatment and continues to increase even after the serum $\mathrm{Fe}$ levels pass their peak. In addition, transferrin is important to $\mathrm{Fe}$ homeostasis, as it is involved in the transportation of $\mathrm{Fe}$ between the bloodstream and tissues. A significant decline in transferrin levels accompanied the increase in serum $\mathrm{Fe}$ and ferritin, although the capacity of transferrin to store $\mathrm{Fe}$ is markedly lower than that of ferritin from a stoichiometric viewpoint. These findings indicate that the change in serum ferritin and transferrin levels was a secondary reaction against excessive $\mathrm{Fe}$ in the bloodstream. In esophageal patients undergoing CDDP-based chemotherapy, Akutsu et al (17) demonstrated the decreased serum $\mathrm{Cu}$ and $\mathrm{Mn}$ levels and the marginal change in serum $\mathrm{Fe}$ and $\mathrm{Zn}$ levels, although the methodology used to measure the trace metals was not clear. The variations detected were markedly different when compared with those of the present study, which may be due to the differing nutritional status of the patients; in the former study, patients received total parenteral nutrition, but not in the present study. Overall, although the present pilot study was limited by its small sample size in each type of cancer and combined chemotherapeutic agent, it was concluded that the transient elevation in serum Fe levels after CDDP treatment is not completely explained by destruction of red blood cells and/or ferritin, and further studies are required to address this issue.

As shown in Fig. 3, the plasma concentration of ${ }^{66} \mathrm{Zn}$ in esophageal and lung cancer patients without blood transfusion or meal intake was increased on days 1-3 after the CDDP treatment and, subsequently, varied without a certain tendency. By contrast, Sweeney et al (14) reported that a decrease in plasma $\mathrm{Zn}$ following CDDP administration, which was accompanied by an increase in urinary $\mathrm{Zn}$ excretion, and diurnal variation in plasma $\mathrm{Zn}$ level were observed in the head and neck, and lung cancer patients. The authors also discussed the possibility of the release of intracellular $\mathrm{Zn}$ by tumor lysis following CDDP administration, which would lead to an increase in plasma $\mathrm{Zn}$ concentration (14). Additionally, it was reported that, in CDDP-treated rat kidneys, $\mathrm{Zn}$ that was bound to proteins within cells could be displaced by Pt, although the serum $\mathrm{Zn}$ levels were not clearly known (5). In the present study, $\mathrm{Zn}$ possibly derived from the kidneys may be involved in the increase in plasma $\mathrm{Zn}$ levels immediately following CDDP treatment. However, the extent to which that contributes to the change in plasma $\mathrm{Zn}$ levels remains obscure, and therefore, further studies are warranted to appropriately investigate this possibility.

Cystatin $\mathrm{C}$ is one of the endogenous markers of the glomerular filtration rate (18-20), but the efficacy of blood cystatin C level for detection of renal dysfunction during CDDP-based chemotherapy remains controversial (21-23). In our previous study, a transient elevation of serum cystatin $\mathrm{C}$ concentration, 
perhaps independently of renal function, was observed in esophageal cancer patients receiving CDDP-based chemotherapy (6). In the present study, two lung cancer patients exhibited an increase in the plasma cystatin $\mathrm{C}$ concentration within a week after the CDDP treatment, followed by a subsequent return to baseline levels (Fig. 5). Another lung cancer patient also appeared to exhibit a similar tendency, although this patient did not fast for the baseline blood sampling (Fig. 5). These findings were in close agreement with our previous results, and indicated a possible underestimation of renal function based on plasma cystatin $\mathrm{C}$ levels during the early CDDP treatment period, regardless of whether the cancer was of the lung or the esophagus (6). Prospective and larger clinical studies are required to confirm these findings.

As mentioned above, a transient elevation was observed in serum Fe levels, and this change appeared to be parallel to that of plasma cystatin $\mathrm{C}$ levels (Figs. 2, 3, 4A and 5). In patients receiving CDDP-based chemotherapy, antiemetic therapeutic agents, including dexamethasone are administered to prevent treatment-associated nausea and vomiting (24), while dexamethasone has the potential to induce the secretion of cystatin $\mathrm{C}$ from cancer cell lines $(25,26)$. It was reported that an increase in serum $\mathrm{Fe}$ levels and a decrease in total $\mathrm{Fe}$ binding capacity calculated based on serum transferrin levels were observed only during an anti-inflammatory period induced by the administration of prednisolone in an experimental dog study (27). If dexamethasone exerted an effect similar to that of prednisolone immediately after initiating CDDP-based chemotherapy, the increase in serum Fe levels may reflect the phenomenon of anti-inflammation induced by dexamethasone. Although it remains unclear whether the extracellular release of $\mathrm{Fe}$ is correlated with that of cystatin $\mathrm{C}$ and whether Fe influences the measurement system of cystatin $\mathrm{C}$, the evaluation of renal function based on serum levels of not only cystatin $\mathrm{C}$, but also $\mathrm{Fe}$, would be more reliable during the early CDDP treatment period.

The progressive decline in magnesium levels with each successive cycle of chemotherapy has been reported in patients receiving CDDP-based chemotherapy (28). In the present study, serum magnesium levels tended to decrease after the start of chemotherapy and its median level at the end of the observation period was 0.92 (quartile range, 0.87-0.99) of the baseline level (Fig. 4B). The value was comparable with those in previous reports $(28,29)$. Furthermore, the protective effect of magnesium supplementation and the preventive effect of magnesium preloading on nephrotoxicity in cancer patients receiving CDDP-based chemotherapy have been reported (30,31); therefore, the underlying mechanisms may become clearer through examination of the effect of Fe, released by CDDP treatment, on serum and tissue magnesium levels.

In conclusion, these findings suggest that serum $\mathrm{Fe}, \mathrm{Zn}$ and magnesium levels may be useful in understanding the physiological responses in the early stages of CDDP-based chemotherapy, which may be associated with systemic inflammation and/or tissue distribution of CDDP.

\section{Acknowledgements}

The present study was supported in part by a Grant-in-Aid for Scientific Research (C) from the Japan Society for the Promotion of Science (grant nos. 26460245 and 16K08908). In addition, it was supported in part by a grant from the Ministry of Education, Culture, Sports, Science and Technology of Japan-Supported Program for the Strategic Research Foundation at Private Universities, 2012-2016 (grant no. S1201008).

\section{References}

1. Madias NE and Harrington JT: Platinum nephrotoxicity. Am J Med 65: 307-314, 1978.

2. Kintzel PE and Dorr RT: Anticancer drug renal toxicity and elimination: Dosing guidelines for altered renal function. Cancer Treat Rev 21: 33-64, 1995.

3. Filipski KK, Mathijssen RH, Mikkelsen TS, Schinkel AH and Sparreboom A: Contribution of organic cation transporter 2 (OCT2) to cisplatin-induced nephrotoxicity. Clin Pharmacol Ther 86: 396-402, 2009.

4. Nakamura T, Yonezawa A, Hashimoto S, Katsura T and Inui K: Disruption of multidrug and toxin extrusion MATE1 potentiates cisplatin-induced nephrotoxicity. Biochem Pharmacol 80: 1762-1767, 2010

5. Moreno-Gordaliza E, Giesen C, Lázaro A, Esteban-Fernández D, Humanes B, Cañas B, Panne U, Tejedor A, Jakubowski N and Gómez-Gómez MM: Elemental bioimaging in kidney by LA-ICP-MS as a tool to study nephrotoxicity and renal protective strategies in cisplatin therapies. Anal Chem 83: 7933-7940, 2011.

6. Kume M, Yasui H, Yoshikawa Y, Horinouchi M, Higashiguchi K, Kobayashi Y, Kuroda D, Hirano T, Hirai M and Nakamura T: Transient elevation of serum cystatin $\mathrm{C}$ concentrations during perioperative cisplatin-based chemotherapy in esophageal cancer patients. Cancer Chemother Pharmacol 69: 1537-1544, 2012.

7. Muñoz M, García-Erce JA and Remacha AF: Disorders of iron metabolism. Part 1: Molecular basis of iron homoeostasis. J Clin Pathol 64: 281-286, 2011.

8. Chasapis CT, Loutsidou AC, Spiliopoulou CA and Stefanidou ME: Zinc and human health: An update. Arch Toxicol 86: 521-534, 2012.

9. Bost M, Houdart S, Oberli M, Kalonji E, Huneau JF and Margaritis I: Dietary copper and human health: Current evidence and unresolved issues. J Trace Elem Med Biol 35: 107-115, 2016.

10. Cobanoglu U, Demir H, Sayir F, Duran M and Mergan D: Some mineral, trace element and heavy metal concentrations in lung cancer. Asian Pac J Cancer Prev 11: 1383-1388, 2010.

11. Zowczak M, Iskra M, Torliński L and Cofta S: Analysis of serum copper and zinc concentrations in cancer patients. Biol Trace Elem Res 82: 1-8, 2001.

12. Díez M, Arroyo M, Cerdàn FJ, Muñoz M, Martin MA and Balibrea JL: Serum and tissue trace metal levels in lung cancer. Oncology 46: 230-234, 1989.

13. Issell BF, MacFadyen BV, Gum ET, Valdivieso M, Dudrick SJ and Bodey GP: Serum zinc levels in lung cancer patients. Cancer 47: 1845-1848, 1981.

14. Sweeney JD, Ziegler P, Pruet C and Spaulding MB: Hyperzincuria and hypozincemia in patients treated with cisplatin. Cancer 63: 2093-2095, 1989.

15. Wang LS, Lin HY, Chang CJ, Fahn HJ, Huang MH and Lin CF: Effects of en bloc esophagectomy on nutritional and immune status in patients with esophageal carcinoma. J Surg Oncol 67: 90-98, 1998.

16. Ganz T: Systemic iron homeostasis. Physiol Rev 93: 1721-1741, 2013.

17. Akutsu Y,Kono T, Uesato M,Hoshino I, Murakami K, Fujishiro T, Imanishi $\mathrm{S}$, Endo $\mathrm{S}$, Toyozumi T and Matsubara $\mathrm{H}$ : Are additional trace elements necessary in total parenteral nutrition for patients with esophageal cancer receiving cisplatin-based chemotherapy? Biol Trace Elem Res 150: 109-115, 2012.

18. Filler G,Bökenkamp A,Hofmann W,Le Bricon T, Martínez-Brú C and Grubb A: Cystatin C as a marker of GFR--history, indications, and future research. Clin Biochem 38: 1-8, 2005.

19. Newman DJ: Cystatin C. Ann Clin Biochem 39: 89-104, 2002.

20. Chew JS, Saleem M, Florkowski CM and George PM: Cystatin C - a paradigm of evidence based laboratory medicine. Clin Biochem Rev 29: 47-62, 2008.

21. Oc MA, Demir H, Cekmen MB, Isgoren S, Gorur GD and Bilgili $\mathrm{U}$ : Correlation of Cystatin-C and radionuclidic measurement method of glomerular filtration rate in patients with lung cancer receiving cisplatin treatment. Ren Fail 36: 1043-1050, 2014 
22. Kos FT, Sendur MA, Aksoy S, Sezer S, Civelek B, Yazici O, Yaman S, Eren T and Zengin N: Evaluation of the renal function using cystatin $\mathrm{C}$ level in the patients receiving cisplatin-based chemotherapy. Ren Fail 35: 705-710, 2013.

23. Bodnar L, Wcislo GB, Smoter M, Gasowska-Bodnar A, Stec R, Synowiec A and Szczylik C: Cystatin C as a parameter of glomerular filtration rate in patients with ovarian cancer. Kidney Blood Press Res 33: 360-367, 2010.

24. Kris MG, Hesketh PJ, Somerfield MR, Feyer P, Clark-Snow R, Koeller JM, Morrow GR, Chinnery LW, Chesney MJ, Gralla RJ, et al; American Society of Clinical Oncology: American Society of Clinical Oncology guideline for antiemetics in oncology: Update 2006. J Clin Oncol 24: 2932-2947, 2006.

25. Bjarnadóttir M, Grubb A and Olafsson I: Promoter-mediated, dexamethasone-induced increase in cystatin $\mathrm{C}$ production by HeLa cells. Scand J Clin Lab Invest 55: 617-623, 1995.

26. Yamawaki C, Takahashi M, Takara K, Kume M, Hirai M, Yasui $\mathrm{H}$ and Nakamura T: Effect of dexamethasone on extracellular secretion of cystatin $\mathrm{C}$ in cancer cell lines. Biomed Rep 1: 115-118, 2013.

27. Adamama-Moraitou KK, Saridomichelakis MN, Polizopoulou Z, Kritsepi M, Tsompanakou A and Koutinas AF: Short-term exogenous glucocorticosteroidal effect on iron and copper status in canine leishmaniasis (Leishmania infantum). Can J Vet Res 69: 287-292, 2005.
28. Hodgkinson E, Neville-Webbe HL and Coleman RE: Magnesium depletion in patients receiving cisplatin-based chemotherapy. Clin Oncol (R Coll Radiol) 18: 710-718, 2006.

29. Abbasciano V, Mazzotta D, Vecchiatti G, Tassinari D, Nielsen I and Sartori S: Changes in serum, erythrocyte, and urinary magnesium after a single dose of cisplatin combination chemotherapy. Magnes Res 4: 123-125, 1991.

30. Bodnar L, Wcislo G, Gasowska-Bodnar A, Synowiec A Szarlej-Wcisło K and Szczylik C: Renal protection with magnesium subcarbonate and magnesium sulphate in patients with epithelial ovarian cancer after cisplatin and paclitaxel chemotherapy: A randomised phase II study. Eur J Cancer 44: 2608-2614, 2008

31. Yoshida T, Niho S, Toda M, Goto K, Yoh K, Umemura S, Matsumoto S, Ohmatsu $\mathrm{H}$ and Ohe Y: Protective effect of magnesium preloading on cisplatin-induced nephrotoxicity: A retrospective study. Jpn J Clin Oncol 44: 346-354, 2014. 